\title{
IMPACT OF PAK-INDIA TRADE ON ECONOMY OF PAKISTAN BY USING COMPUTABLE GENERAL EQUILIBIUM MODEL (CGE)
}

\author{
Dr.Nadeem Bhatti
}

68 Corporate Drive, Suite \# 1626 Scarborough, ON, M1H 3H3, Canada

Faiz Muhammad Shaikh

Assistant Professor SZABAC-Dokri-Larkana-Sindh, Pakistan

Dr.Anwar Ali Shah G.Syed

Pro-Vice Chancellor Sindh University Campus Dadu

\section{ABSTRACT}

This research investigates the Impact of PAK-INDIA trade on Economy of Pakistan. Data were collected from GTAP-7 database and six sectors were included in the database, Textile, Pharmaceutical, Automobile parts and engineering, Agriculture, Financial and Insurance services and logistics. Data were analyzed by using GEM-software. Different simulation run on GTAP-7 database and various tariff rates applied. It was revealed that if India were removing the sensitive list item, in this scenario both countries would have positive impact on GDP, Export, Import and Employment of Pakistan. The results indicates that there in Agriculture, textile, Auto Pakistan's is head on India in MFN status. In Pharmaceutical, Financial services and Logistics India has positive gain. It was further revealed that if Pakistan is given MFN status to India, Pakistan's import decreased and Export increased and overall positive impact on Economy. This research analyzes the potential economic costs and benefits of Pak-India trade in Textile, Pharmaceutical, Automobile parts and engineering, Agriculture, Financial and Insurance services and logistics. The first scenario is when normal trading relation with India will be restored; it means that both countries will give the MFN (Most Favored Nations) status to each other. In the second scenario, the SAFTA will be operative and there will be free trade between India and Pakistan and both countries will remove all tariffs and custom duties from each others' imports. The Global trade analysis GTAP model is used to analyze the possible impact of SAFTA on Pakistan in a multi country, multi sector applied General equilibrium frame work. After employing the simplified static analysis framework, the analysis based on simulations reveals that current demand for Pakistani Textile, Pharmaceutical, Automobile parts and engineering, Agriculture, Financial and Insurance services and logistics will expand after the FTA and consumer surplus will increase. The drop in the domestic prices of dates will increase the production of many downstream industries, which will have pleasant multiplier effects on the economy of Pakistan. The government may reduce MFN tariffs on industrial dates before implementing the FTA. A key rule of multilateral trade system is that the reduction in trade barriers should be applied on a most-favored nation basis (MFN) to all WTO members. The only exception to the MFN principle built into the GATT legal framework is the provision for reciprocal free trade within customs unions and free trade areas (GATT article XXIV). Following the analytical framework discussed by PO managerial (2001), we employ the simplified static analysis by using CGE model for policy implication, which reveals that Pakistan will gain benefit from Pak-India trade. Results based on this research reveal that on SAFTA, grounds, here will be net export benefits in Pakistan's economy.

Key Words, PAK-INDIA, TRADE, CGE

\section{Council for Innovative Research}

Peer Review Research Publishing System

\section{JOURNAL: International Journal OF Management \& Information Technology}

\author{
Vol . 11, No 1 \\ editorsijmit@gmail.com
}

www.ijmit.com 
1. Introduction: Trade liberalization was the key element of this new policy package and it entailed reliance on tariffs, replacement of quantitative restrictions including import licensing by a revised system of tariffs as well as the relaxation of other controls on trade. In order to encourage both domestic and foreign investment, the Government offered a series of incentives, while attempting to create an environment conducive to investment. In recent years, however, the focus of Pakistan's trade policy has seemingly shifted towards regionalism, which Pakistan considers a springboard for broader trade liberalization. The rationale for regional cooperation is based on a number of factors, not all of which are necessarily economic in nature. Until the late 1970s, Pakistan's economic development centered on an inward-oriented development strategy based on import substitution industrialization performed mainly by state owned firms. Both tariff and non-tariff barriers were widely used to protect domestic economic activities. Trade restrictive policies were accompanied by other regulatory policies such as control on foreign exchange, finance and foreign direct investment. These restrictive economic policies had severe adverse implications on overall economic growth, in particular growth of exports. Pakistan introduced extensive economic reforms in 1971-72 becoming the first country in the South Asian region to do so. The economy was freed from the inward-oriented strategy, and adopted an outward-oriented export-led development strategy, which was followed by many East Asian countries at that time. This research begins with a review of Pakistan's economic reforms and their coverage. The methodology, will offer a brief description of CGE Modeling including the GTAP. Then we will discuss experimental designs are discussed. Through the model we form unilateral and regional trade liberalization, as a founding member of the WTO, Pakistan as a member firmly committed to the multilateral trading system and has already establish a large number of reforms in keeping with the GATTMTO principles. However, this study will review the outcome of multilateral trade Liberalization. The GTAP model simulation will be analyzed.

\section{Research Problem}

The formation of EU, NAFTA, MERCOSUR and ASEAN, and the recent emergence of other regional trading blocs may have given rise to a revival of interest in regionalism in Pakistan. This also explains the country's desire to avoid marginalization as more and more countries become members of various RTAs, (Baldwin, 1993). Further, an RTA facilitates the choice of a selective liberalization policy as mutually agreed by all member economies, keeping them protected from global competition. Thus, Pakistan continued to 5 promote international trade through active participation in several regional trading agreements such as South Asian Preferential Trading Agreement (SAPTA), 7 India-Sri-Lanka Free Trade Agreement (ILFTA), 8 Bangkok Agreement (BA) 9, the Bay of Bengal Initiative for Multi sectorial Technical and Economic Cooperation (BIMST-EC) 10 comprising Bangladesh, India, Myanmar, Pakistan and Thailand and Indian Ocean Rim Association for Regional Cooperation (IORARC). The Free Trade Agreement (FTA) between Pakistan (PLFTA) became operational from June 2005. SAFTA was the first major step in moving towards a free trade area and higher forms of regional economic integration among the member states of the South Asian Association for Regional Cooperation (SAARC). Member countries consisting of Bangladesh, Bhutan, India, Maldives, Nepal, Pakistan and Pakistan established SAARC in 1985. The SAAC members, providing a legal framework for trade liberalization and strengthening intra-regional economic cooperation, signed the agreement on SAFTA in Dhaka in April 1993. In 1995, SAFTA had been ratified by all contracting states and in accordance with Article 22 of the agreement SAFTA became operational on 7th December 1995. SAFTA followed a positive list approach, including flexible provisions for least developed countries (LDCs). At the Ninth SAARC Summit held in Male in 1997, the Heads of Governments decided to accelerate the pace of transition of SAFTA to South Asian Free Trade Agreement (SAFTA) by the year 2001 or Consumption is also quite high during Christmas. Similarly, the fruit enjoys enormous significance on the occasion of Dial and such festivals another religion. In Europe and North America, the fruit is particularly preferred during the dark winter month. Usual sales of dates are spread to a period from October to April. The current research focus on Pak-India trade relationship on moving towards MFN.

\section{OBJECTIVES}

he objectives of the present study are to analyze and quantify the potential economic cost and benefits of the prospective trade between India and Pakistan Trade on on GDP, Employment, Export and Imports.

o analyze the Welfare effects of host country on Pak-India Trade

-

o explore the welfare gain/loss on MFN

-

o determine the impact on the economy of Pakistan

\section{Literature Review}

Regional trade agreements (RTAs) have emerged as an alternative to achieve trade liberalization as multilateral efforts have faced

political and economic obstacles. ${ }^{2,3}$ The difficulties of reaching agreements on sensitive issues like agriculture and services have

been evident in the Doha Round. The previous rounds were also marked by complex and slow negotiation processes. 


\section{ISSN 2278-5612}

For one, as

the number of participants increases, it has been more difficult to address each country's demands for special consideration RTAs

convey advantages as well as limitations. By reducing the number of participants in the negotiation they can help expand the discussion

to include more dimensions of economic integration. Compared with unilateral liberalization, political support for RTAs also seems to

be greater given the perception of reciprocity from other member countries. However, since the early work of Viner (1950), these

benefits have been weighted against distortions that RTAs can create. By de facto discriminating against nonmembers, RTAs

distort resource allocation, favoring regional producers to the potential detriment of local consumers. Recent research also emphasizes

the global consequences of multiple and overlapping RTAs in terms of the transaction costs they impose (Ferid hanusetyawan, 2005).

Although RTAs have varied components, these agreements include some or all of the following eight elements (Bhagwati and Panagariya, 1996 provide an overview): (i) a tariff liberalization program-TLP (transformation of nontariff barriers, e.g. quotas, to their tariff equivalent and the sequential reduction of tariffs; special considerations to least developed countries ${ }^{4}$ are not uncommon); (ii) sensitive lists (goods or services to be exempt from the tariff reduction program); ${ }^{5}$ (iii) rules of origin-ROO (prevention of the application of the preferential tariffs to non regional goods or services as defined by the agreement); ${ }^{6}$ (iv) institutional arrangements (establishment of a council or administrative committee responsible for the administration and implementation of the agreement); $(v)$ trade facilitation policies (collection of instruments to reduce transaction costs of importing and The literature about trade agreements is rich in acronyms that denote either their geographical extension or their degree of trade barrier reductions. RTAs refer to agreements involving regional partners. Free Trade Agreements (FTAs) refers to agreements that includes the full elimination of tariffs (and trade barriers) while Preferential Trade Agreements (PTAs) s refer to agreements involving partial tariff elimination. For example, SAPTA is South Asia's PTA and SAFTA is South Asia's FTA.Exporting, including homogenization of customs practices and technical assistance specially to the least-developed members); (vi) dispute settlement mechanism (procedures to report and deal with violations to the agreement); (vii) safeguards measures (suspension of preferential treatment on grounds that imports are causing or threatening to cause serious injury to the domestic industrial base); and (viii) parallel reduction in foreign investment barriers and/or trade in services.

South Asia (Bangladesh, Bhutan, India, Maldives, Nepal, Pakistan and Sri Lanka) has been involved in setting up its own RTA. The South Asian Association for Regional Cooperation(SAARC) was formed in 1985 with the objective of exploiting "accelerated economic growth, social progress and cultural development in the region" for the welfare of the peoples of South Asia (SAARC Secretariat, 2006). In 1995, its corresponding RTA (SAPTA) came into force. South Asian Free Trade Agreement (SAFTA) has been ratified and entered into force in mid-2006. In comparison to other African countries, over the past two decades attention of researchers, government, and donors has been focused in Kenya's horticultural and floriculture sectors due to their capacity to grow rapidly and yet sustainably to meet international standards (Jaffee, 2004). The production highly oriented to export markets can be track back at the farm level. While over $90 \%$ of smallholder farmers in all but the arid regions of Kenya produce horticultural products, less than $8 \%$ cultivate other kind of crops (Tschirley, et al, 2004). SAFTA is expected to increase regional trade (trade creation) but may do so at the expense of trade flows from more efficient non regional suppliers (trade diversion). Baysan and others (2006) argue that it is unlikely that the most efficient suppliers of the member countries are within the region. Based on that and on the restrictiveness of SAFTA's sensitive lists and rules of origin, it concludes the economic merits of SAFTA are "quite weak." Using the static general equilibrium methodology, Bandara and Yu (2003) find that the full elimination of trade barriers between South Asian countries would increase the welfare level of India. To study the effects of RTAs on trade flows, typically the gravity equation approach is used. In its simplest version, it postulates a relationship between the "mass" (GDP) of two countries and their trade flows. In practical terms, the approach offers a "conditional general equilibrium" relation (Anderson and van Wincoop, 2004) in which bilateral trade is modeled as independent of trade flows with third party countries.

Gravity equations have also been used to measure unobserved trade barriers, to discriminate between theoretical trade models, and to analyze the effects of trade policies (either in an ex-post or ex-ante fashion). ${ }^{11}$ The latter has been subject to critiques and refinements (e.g., Carrère, 2006) among the most important being that for the gravity equation analysis to be appropriate one needs to assume (or "condition on") that the policy changes being

Anderson and van Wincoop (2004); and Feenstra, Markusen, and Rose (2001). aconsidered do not modify the basic relation between countries' masses and their trade flows. ${ }^{12}$ Given the relative small size of South Asian countries in the world markets such an assumption appears not to be problematic for the scenarios considered here. In summary, the general equilibrium approach offers the possibility of answering a richer set of questions but demands data not readily accessible for some of the countries we are interested in. ${ }^{13}$ Although the evaluation of the benefits and limitations of each methodology is beyond the scope of this paper it can be argued that they are complementary rather than substitutes. This paper uses a gravity equation approach and builds on Srinivasan (1994). In particular, it allows the response to trade 
barriers to differ by source of the goods; treats independently imports and exports of each country pair; and includes all seven members of SAFTA in the analysis. As Bandara and Yu (2003) and Gilbert, Scollay, and Bora (2001) show, welfare and trade volume do not necessarily follow a monotonic relationship and interpreting gravity equation results as describing desirability or welfare can be misleading. ${ }^{15}$ Nevertheless, by providing three different criteria-trade flows, trade balance and customs revenue - the paper provides information on the relative merits of alternative arrangements.

\section{METHODOLOGY}

It is widely acknowledged that computable general Equilibrium (CGE) modeling has become the tool of choice for analysis of a wide range of trade policy issues such as tariffs and non-tariff barriers (NTBs) in both developed and developing countries in a variety of settings. In particular, CGE modeling is useful for analyzing the welfare effects of trade policy that needs to address second-best issues, where there are significant interactions between policy measures for one sector and distortions elsewhere in the economy. Such models have two distinctive features: they incorporate a number of distinct sectors, and the behavioral equations of the model deal with the response of industries and consumers to changes in relative prices (Adams et al., 1998). This development is explained by the capability of CGE models to provide an elaborate and realistic representation of the economy, including the linkages between all agents, sectors and other economies (Brockmeier, 1996) CGE analysis also provides a valuable tool for putting things in an economy-wide perspective (Hertel, 1999).

\section{THE GTAP MODEL}

In this study, the widely used Global Trade Analysis Project (GTAP), a multi-country, multisector CGE model (Hertel, 1997) has been employed to empirically assess the impact of trade liberalization reforms on Pak-India trade. Multicountry, economy-wide CGE models are designed to work out the relative prices of various inputs and outputs mixes of the economies of interest as well as indicating the global changes in world trade patterns. Thus, the strength of a global CGE model lies in its ability to help us understand the linkages between sectors, countries and factors on a global scale. The general equilibrium structure recognizes that all parts of the world economy hinge together in a network of direct and indirect linkages. This means that any change in any part of the system will, in principle, have repercussions throughout the entire world. As McDougall (1995, p. 88) clearly points out "its characteristics are that it is economy-wide, it is multisectoral, and it gives a central role to the price mechanism. These characteristics differentiate it from partial equilibrium modeling (not economy-wide), macroeconomic modeling (not multi-sectoral), and input-output modeling (agents don't respond to price signals)."The GTAP model was designed for comparative-static analysis of trade policy issues in an economy-wide framework. Since the changes in trade policies and production levels in any of the regions and sectors will have impacts on other regions and sectors, even though my main focus of this study is on results for Pakistan, it is possible to incorporate the policy changes of other countries within a global CGE modeling framework.

\section{Data Set}

Data will be collected from secondary sources GTAP-7 data base

\section{LIMITATIONS OF THE CGE MODEL}

Despite the importance of CGE modeling in policy analysis, a series of questions have been raised about the empirical validity of these models. The core of the critique is focused on unsound parameter selection criteria, because the choice of elasticity values critically affects the results of policy simulations generated by these models. In the calibration method, some parameters are determined on the basis of a survey of empirical literature, some chosen arbitrarily, and the remainders are set at values, which force the model to replicate the data of a chosen benchmark year (Shoven and Whalley, 1992). Most often the estimated elasticities for commodity and/or industry classifications are based on econometric studies, which are not totally consistent with the countries represented in the model or they may even be "guesstimates" when no published figures are available.

\section{Instrument}

- GTAP-Model

- Variables PAK-INDIA TRADE (Independent variable)

- SAFTA (Dependent Variable)

- Dependent Variables

- Textiles (Dependent Variable)

- Pharmaceuticals (Dependent Variable)

- Automotive parts and engineering(Dependent Variable)

- Agriculture(Dependent Variable)

- Financial an insurance services(Dependent Variable) 
- GTAP-Model ((Hertel, 1997) GTAP-7 Data Base

- Data will be analyzed by using GEMS Software

Sectors:

Codes

Agriculture

AGRI

AUTO

AUTO

TEXTILE

TEXT

PHARMACETICAL

PHAR

INSURANCE AND FINANCIAL SERVICES OFI ISR

TRANSPORT AND LOGISTICS

OTPL

SOURCE-GTAP-DATA BASE-7

Pak-India Trade Model

Aggregated Regions GTAP Region

1. Pakistan (PK) Pakistan

2. India (IND) India

3. Rest of South Asia

Sri Lanka, Bangladesh, Bhutan, Maldives, Nepal

4. Rest of the World (ROW all other Countries

SHAIKH (2013)

Pak-India Trade Project

Table 1: Experiment-115 Percent Uniform Import Tariffs Estimated Percentage Changes in Regional Output and Trade Sector IND PAK XSA XWA

(a)

Industry Output (In Millions)

\begin{tabular}{|l|c|c|c|c|}
\hline AGRI & $\mathbf{- . 0 2}$ & $\mathbf{0 . 7 7}$ & 0.07 & -0.03 \\
\hline PHAR & $\mathbf{3 . 7 8 6 1}$ & $\mathbf{1 . 3 4}$ & -0.06 & 0.05 \\
\hline AUT & $\mathbf{4 . 0 2}$ & $\mathbf{1 . 5 7}$ & 0.05 & 0.03 \\
\hline TEXT & $\mathbf{1 . 4 5 . 0 3}$ & $\mathbf{2 . 6 0}$ & 0.01 & 0.11 \\
\hline OFIISR & $\mathbf{- 0 . 1 3}$ & $\mathbf{8 . 4 3}$ & -0.11 & -0.20 \\
\hline OTPL & $\mathbf{- 0 . 0 1}$ & $\mathbf{2 0 . 5 5}$ & 0.00 & -0.03 \\
\hline (b) Export & (In Millions) \\
\hline AGRI & $\mathbf{1 . 4 4}$ & $\mathbf{1 . 0 0}$ & 0.07 & -0.03 \\
\hline PHAR & $\mathbf{0 . 0 1}$ & $\mathbf{0 . 9 0}$ & -0.06 & 0.05 \\
\hline AUT & $\mathbf{0 . 1 9}$ & $\mathbf{- 1 . 1 4}$ & 0.05 & 0.03 \\
\hline TEXT & $\mathbf{- 0 . 1 6}$ & $\mathbf{6 . 7 9}$ & 0.01 & 0.11 \\
\hline OFIISR & $\mathbf{- 0 . 2 8}$ & $\mathbf{2 . 4 8}$ & -0.11 & -0.20 \\
\hline OTPL & $\mathbf{- 0 . 0 0}$ & $\mathbf{2 . 5 7}$ & 0.00 & -0.03 \\
\hline
\end{tabular}


Tariff Rates

$5 \%$ SAFTA

$15 \%$

Table 2: Experiment-2 South Asian Free Trade Agreement - SAFTA- Estimated Welfare and Trade Effects

\begin{tabular}{|c|c|c|c|c|c|c|c|c|}
\hline Countries & EV US\$ & $\%$ of GDP & TOT & Vol-Export & Volume-Import & Export Price & Import-Price & DTBAL US\$ \\
\hline IND & 5434.97 & 4.34 & $\begin{array}{l}0.8 \\
0 \\
\end{array}$ & 5.40 & 4.00 & 9.38 & 8.68 & $-1100.90 \mathrm{~m}$ \\
\hline PAK & 5643.63 & 6.35 & $\begin{array}{l}0.9 \\
9\end{array}$ & 7.11 & 7.77 & 5.97 & 7.44 & $-786.77 m$ \\
\hline RAS & -1592.56 & -1.74 & -0.57 & -3.92 & 31.54 & 24.83 & -2.12 & $-1322.73 m$ \\
\hline XSA & -375.79 & -0.02 & 0.0 & -0.04 & 0.00 & -0.06 & -0.05 & $149.69 m$ \\
\hline
\end{tabular}

Tariff Rates

SAFTA $=5 \%$

$\mathrm{MFN}=10 \%$

$X W A=10 \%$

SAFTA $=10$

The trade reform scenario (Experiment-2) was conducted under the regional trade liberalization policy option to examine the impact of South Asian Free Trade Agreement- SAFTA in different contexts from the perspective of Pakistan. As a member of the SAFTA, Pakistan. committed to continue major trade liberalization measures, to establish and promote free trade arrangements for strengthening inter-regional economic co-operation and the development of national economies. In this experiment, it was assumed that Pakistan and each of the SAARC member countries in the model (India and the Rest of South Asia comprising Bangladesh, Bhutan, Maldives, Nepal and Sri lanka) remove their tariffs against each other, while maintaining heir tariffs against the rest of the South Asia.

Table 3: Experiment-210 Percent Uniform Import Tariffs Estimated Percentage Changes in Regional Output and Trade

(a) Industry Output

\begin{tabular}{|l|c|c|c|c|}
\multicolumn{1}{c}{ Sector } & \multicolumn{1}{c}{ IND } & \multicolumn{1}{c|}{ XSA } & XWA \\
\hline AGRI & $\mathbf{8 . 5 5}$ & $\mathbf{1 . 7 9}$ & 0.08 & -0.08 \\
\hline PHAR & $\mathbf{4 . 6 0}$ & $\mathbf{- 0 . 9 1}$ & -0.06 & 0.06 \\
\hline AUT & $\mathbf{3 . 0 2}$ & $\mathbf{0 . 5 7}$ & 0.05 & 0.03 \\
\hline TEXT & $\mathbf{0 . 0 3}$ & $\mathbf{0 . 6 0}$ & 0.01 & 0.11 \\
\hline OFIISR & $\mathbf{- 0 . 1 3}$ & $\mathbf{8 . 4 3}$ & -0.11 & -0.20 \\
\hline OTPL & $\mathbf{- 0 . 0 1}$ & $\mathbf{2 0 . 5 5}$ & 0.00 & -0.30 \\
\hline EXPOHS & & & &
\end{tabular}

\begin{tabular}{|l|c|c|c|c|}
\hline Exports \\
\hline AGRI & $\mathbf{0 . 4 5}$ & $\mathbf{2 . 0 0}$ & 0.05 & -0.07 \\
\hline PHAR & $\mathbf{0 . 0 6}$ & $\mathbf{- 7 . 1 3}$ & -0.06 & 0.05 \\
\hline AUT & $\mathbf{0 . 1 9}$ & $\mathbf{- 9 . 1 4}$ & 0.05 & 0.03 \\
\hline TEXT & $\mathbf{- 0 . 1 6}$ & $\mathbf{8 . 7 9}$ & 0.01 & 0.11 \\
\hline OFIISR & $\mathbf{- 0 . 2 8}$ & $\mathbf{2 . 4 8}$ & -0.11 & -0.20 \\
\hline OTPL & $\mathbf{- 0 . 0 0}$ & $\mathbf{2 . 5 7}$ & 0.00 & -0.03 \\
\hline & & & & \\
\hline
\end{tabular}


Tariff Rates

SAFTA $=5 \%$

$\mathrm{MFN}=10 \%$

$\mathrm{XWA}=10 \%$

$\mathrm{SAFTA}=10$

The trade reform scenario (Experiment-2) was conducted under the regional trade liberalization policy option to examine the impact of South Asian Free Trade Agreement- SAFTA in different contexts from the perspective of Pakistan. As a member of the SAFTA, Pakistan. committed to continue major trade liberalization measures, to establish and promote free trad arrangements for strengthening inter-regional economic co-operation and the development of national economies. In this experiment, it was assumed that Pakistan and each of the SAARC member countries in the model (India and the Rest of South Asia comprising Bangladesh, Bhutan, Maldives, Nepal and Sri lanka) remove their tariffs against each other, while maintaining heir tariffs against the rest of the South Asia. According to results in SAFTA 5\% tariff the Pakistan industry output .079 compare to India -0.4 that Pakistan's will benefit on SAFTA trade with India. Indian industry out put show s that in Auto, Textile India's position is better in compare with Pakistan.

The Second experiment considered that Pakistan's reduction of import tariffs to 10 percent under the unilateral trade liberalization. The impact of this scenario on regional welfare and the resulting percentage changes in sectoral output and trade are reported in Table 3, 4and 5 respectively. Accordingly, if Pakistan reduces its import tariffs to 10 percent unilaterally on a global basis to maintain a uniform external tariff rate, Pakistan's experiences a welfare gain around US $\$ 201$ million (1.53 percent of the GDP). Under this scenario, Pakistan's volume of imports rises by 3.3 percent while its volume of exports falls slightly by 0.3 percent reflecting the fact that the pressure to increase imports is stronger than the increase in demand for Pakistan's exports by unilateral liberalization. However, as a result of the composite export price increase by 1.1 percent, Pakistan's experiences a small improvement in the terms-of-trade of 1.5 percent and the real GDP by 0.8 percent. The welfare gains or losses for other regions are quite varied under this simulation. However, the impact of Pakistan's unilateral reduction of import tariffs to 10 percent will not affect other region's real GDP or terms-of-trade significantly.

Accordingly, the results suggest that a reduction of import tariffs to 10 percent will increase Pakistan's welfare and terms-of-trade as well. Although one might expect that the reduction of import tariffs would increase the domestic output and therefore increase export sales, this policy reform would adversely affect Pakistan's domestic output in most of the sectors because of foreign competition. A similar impact can be seen in export sales too.

Table 4: South Asian Free Trade Agreement-SAFTA (continued) Estimated Percentage Changes in Regional Output and Trade

\begin{tabular}{|l|l|l|c|c|}
\multicolumn{5}{c}{ Regional Output and Trade } \\
Aggregate Exports \\
Sector & PAK & \multicolumn{1}{c|}{ IND } & XSA & XWA \\
\hline AGRI &. $\mathbf{0 9}$ & $\mathbf{- 0 . 1 0}$ & 0.03 & 0.37 \\
\hline PHAR & $-\mathbf{5 0}$ & $\mathbf{0 . 2 2}$ & 0.00 & 0.66 \\
\hline AUTO & $\mathbf{0 . 0 9}$ & $\mathbf{- 1 0 . 5 7}$ & 0.01 & 0.77 \\
\hline TEXT & $\mathbf{- 0 . 0 7 8}$ & $\mathbf{- 5 . 6 0}$ & 0.06 & 0.45 \\
\hline OFI ISR & $\mathbf{- 0 . 2 3}$ & $\mathbf{9 . 4 3}$ & -0.09 & 0.12 \\
\hline OTPL & $\mathbf{- 0 . 2 1}$ & $\mathbf{2 4 . 5 5}$ & 0.00 & 0.33 \\
\hline
\end{tabular}

\section{Aggregate Imports}

\begin{tabular}{|l|l|l|c|c|}
\hline AGRI & $-\mathbf{0 1 1}$ & $\mathbf{0 . 1 0}$ & 0.05 & 0.37 \\
\hline PHAR &.- .10 & $\mathbf{0 . 1 1}$ & 0.02 & 0.66 \\
\hline AUTO & $\mathbf{0 . 5 5}$ & $\mathbf{- 1 0 . 5 7}$ & 0.03 & 0.77 \\
\hline TEXT & $-\mathbf{0 . 7 6}$ & $\mathbf{- 5 . 6 0}$ & 0.03 & 0.45 \\
\hline OFI ISR & $\mathbf{- 0 . 2 3}$ & $\mathbf{6 . 4 3}$ & -0.09 & 0.12 \\
\hline OTPL & $-\mathbf{0 . 2 1}$ & $\mathbf{1 1 . 3 3}$ & 0.01 & 0.33 \\
\hline
\end{tabular}


Table -5: Combined Trade Policy: SAFTA cum 0 Percent Uniform Import Tariffs Estimated Percentage Change in Regional Output and Trade

(a) Aggregate Exports

\begin{tabular}{|c|c|c|c|c|}
\hline Sector & IND & IK & SA & NA \\
\hline AGRI & -.09 & 0.10 & 0.03 & 0.37 \\
\hline DHAR & -.80 & 0.22 & 0.00 & 0.66 \\
\hline AUTO & 0.09 & -10.57 & 0.01 & 0.77 \\
\hline TEXT & -0.078 & -5.60 & 0.06 & 0.45 \\
\hline DFI ISR & -0.23 & 9.43 & -0.09 & 0.12 \\
\hline DTPL & -0.21 & 24.55 & 0.00 & 0.33 \\
\hline
\end{tabular}

Aggregate Imports

Tariff Rate

SAFTA $=0$

$\mathrm{MFN}=8 \%$

$X W A=8 \%$

$\mathrm{XSA}=0$

\begin{tabular}{|l|l|l|c|c|}
\hline AGRI & $-\mathbf{0 3 3}$ & $\mathbf{- 0 . 1 0}$ & 0.07 & 0.17 \\
\hline PHAR & -.40 & $\mathbf{0 . 2 2}$ & 0.04 & 0.12 \\
\hline AUTO & $\mathbf{0 . 0 3}$ & $\mathbf{- 1 0 . 5 7}$ & 0.11 & 0.13 \\
\hline TEXT & $\mathbf{0 . 1 8}$ & $\mathbf{- 5 . 6 0}$ & 0.11 & 0.22 \\
\hline OFI ISR & $\mathbf{- 0 . 1 3}$ & $\mathbf{4 . 4 3}$ & -0.12 & 0.11 \\
\hline OTPL & $\mathbf{- 0 . 2 1}$ & $\mathbf{2 1 . 2 2}$ & 0.11 & 0.31 \\
\hline
\end{tabular}

The Third experiment considered that Pakistan's reduction of import tariffs to 8 percent under the unilateral trade liberalization. The impact of this scenario on regional welfare and the resulting percentage changes in sectorial output and trade are reported in Table 14 and 15 respectively. Accordingly, if Pakistan reduces its import tariffs to 8 percent unilaterally on a global basis to maintain a uniform external tariff rate, Pakistan's EV US\$4564.3 and G.D.P 2.2 percent and India's EV US $\$ 6754$ experiences in this scenario Pakistan's export volume decreasing around US $\$ 101$ million (GDP also decline 2.6 percent of the GDP). Under this scenario, Pakistan's volume of imports rises by 4.3 percent while its volume of exports falls slightly by 1.7 percent reflecting the fact that the pressure to increase imports is stronger than the increase in demand for Pakistan's exports by unilateral liberalization with experience of trade liberalization with India on $8 \%$ tariff. However, as a result of the composite export price decreased by by 2.1 percent, Pakistan's experiences a no improvement in the terms-of-trade of 0.6 percent and the real GDP by 0.3 percent. Th

Experiments 4, 5 \& 6: Sensitivity of the Results

As described previously, to quantify the impact of trade policy reforms on Pakistan's trade with India, three additional experiments were undertaken with an increased elasticity value for the import-import substitution parameter ( Armington parameter)-ESUBM, to consider as Pakistan-India trade relation. Accordingly, under these three experiments, first, the size of the ESUBM increased by 50 percent, and then doubled the value (100 percent increase) to reduce Pakistan's market power in the world market. This would provide an opportunity to examine the sensitivity or robustness of the model predictions with respect to the change in the underlying parameters.

Table 16 presents the results of these three experiments with the central elasticity value scenarios. Thus, under the 15 percent uniform external tariff scenario (E-4), if we reduces Pakistan's market power by increasing the value of ESUBM by 50 percent (E-4.1), it would increase welfare gain around US $\$ 201.84$ million (0.60 percent of the GDP). Similarly, doubling the value (100\%) of ESUBM (E-4.2) would increase Pakistan's welfare by around US\$237.60 million (or 2.41 percent of the GDP). In the former case, the increase in welfare from the central value is 0.44 percent, and in the latter case, it is approximately 0.47 percent. Although these changes are relatively small, it would suggest that even as a big country would be in a position to gain from the unilateral trade liberalization. The welfare increases for the country as the 
elasticities increase. However, under these two scenarios, we small increase in terms-of-trade as elasticities increases. Moreover, under these scenarios, the impact on terms-of-trade is not much different from the central scenario case

Similarly, experiment 5 (E-5) deals with the SAFTA scenario. As shown in Table17, with the increase of the value of ESUBM, both the welfare and the terms-of-trade will increase linearly from the central scenario case. Thus, the welfare gain for Pakistan's under the 50 percent increase in ESUBM (E-5.1) is approximately US $\$ 33.38$ million (2.58 percent of the GDP), whereas under the 100 percent increase scenario (E-5.2), it is around US $\$ 422$ million (2.33 percent of the GDP). Thus the welfare will increase by 4.2 percent from its central value scenario, and in the latter case it will increase by 5.2 percent. Thus, welfare increases as elasticities increase. Thus, the gains are rather linear with both the cases reflecting the robustness of the model results.

Experiment 6 (E-6) considered the combined policy of SAFTA cum 15\% uniform import tariffs scenario Thus, 50\% increase of the value of ESUBM (E-6.1), would increase welfare gain around US\$311million (from US\$221 million at the central scenario) or 5.11 percent of the GDP. Here, the increase in welfare from the central value is 31 percent. Similarly, doubling the value of ESUBM (E-6.2) would increase Pakistan's welfare by around US $\$ 720$ million or 7.22 percent of the GDP. In this case, the increase in welfare from the central value is 61 percent. Moreover, under these two scenarios, the increase in terms-of-trade is 8.0 and 8.8 respectively. Thus the

improvements in the terms of trade from the central value are 1.7 and 3.6 percent respectively. Although these welfare and terms-of-trade gains are not almost linearly related to the changes in the Armington elasticity ESUBM, the result would suggest that unilateral trade liberalization in combination with regional trade liberalization permits Pakistan to expand its export sectors at the same time that all sectors compete more closely with a larger number of competing varieties from abroad.

Table 6. Highlights Pakistan's sectorial output, exports and imports under the sensitivity analysis scenarios. Accordingly, Pakistan's industry output falls significantly in all most all the sectors except for significant increases in Agriculture and Textile wearing apparels. Pakistan's export also decrease considerably under all the experiments as shown in of Table 19, except Textile and agriculture under E-4, and E-5 Auto Parts, under E-6 Parma, and Financial Services and Insurance and Transport and Logistics. India's position in E-6 and E-5 much better compare to Pakistan.

\section{Table7:Sensitivity Analysis (Experiments4,5\&6)Continued}

\section{Estimated percentage Change in Pakistan's Output \&Trade}

(b) Aggregate Exports (millions)

\begin{tabular}{|c|c|c|c|c|c|c|c|c|c|c|}
\hline Sectors & E-4 & E-4-1 & E-4-2 & E-5 & E-5-1 & E 5-2 & E-6 & E-6-1 & E-6-2 & Total \\
\hline AGRI & 2.75 & 3.28 & -15.59 & 35.09 & 55.21 & 70.08 & 26.12 & 49.19 & 49.19 & $63.14 \mathrm{~m}$ \\
\hline PHAR & -6.46 & -10.10 & -11.61 & -15.92 & -19.12 & -17.44 & -19.13 & -30.91 & -30.91 & $-33.23 m$ \\
\hline AUTO & -16.22 & -22.71 & -28.88 & 9.51 & 25.32 & 62.20 & -6.52 & 2.35 & 2.35 & $-29.81 \mathrm{~m}$ \\
\hline TEXT & 3.82 & 2.85 & 4.80 & 3.09 & 27.28 & 29.13 & 8.8 & 16.41 & 16.41 & $18.50 \mathrm{~m}$ \\
\hline OFI ISR & 21.51 & 32.22 & 43.32 & -12.45 & -23.75 & -40.30 & 4.31 & -3.46 & -3.46 & $-15.88 m$ \\
\hline OTPL & 24.63 & 43.42 & 66.39 & -0.14 & -1.42 & -2.11 & 23.41 & 40.20 & 40.20 & $-60.65 m$ \\
\hline \multicolumn{11}{|c|}{ Aggregate Imports (millions) } \\
\hline AGRI & -1.16 & -1.54 & -1.83 & -1.44 & -2.14 & -1.10 & -1.32 & -1.64 & -13.64 & $-3.51 m$ \\
\hline PHAR & -1.61 & -2.57 & -3.34 & 2.15 & 5.42 & 9.91 & -0.62 & 2.87 & 2.87 & $6.31 \mathrm{~m}$ \\
\hline AUTO & 25.87 & 26.21 & 27.25 & 17.88 & 25.73 & 33.92 & 41.31 & 47.54 & 47.54 & $53.21 \mathrm{~m}$ \\
\hline TEXT & -11.89 & -22.23 & -11.20 & -2.18 & -6.33 & -14.21 & 12.61 & 9.24 & 9.24 & $3.43 \mathrm{~m}$ \\
\hline OFI ISR & 20.11 & 29.77 & 39.45 & 2.27 & 12.18 & -28.54 & 6.32 & 0.12 & 0.12 & $44.20 \mathrm{~m}$ \\
\hline OTPL & 5.21 & 6.32 & 7.14 & \begin{tabular}{|l|}
0.91 \\
\end{tabular} & 0.89 & 0.86 & 6.67 & 11 & 11 & $65.18 \mathrm{~m}$ \\
\hline
\end{tabular}

Table19 presents the percentage changes in sectoral output, and trade by region under the SAFTA liberalization. The percentage changes in industry output in Pakistan's, as shown in panel

(a) of Table 7, the performance of the Textile and agriculture sector is remarkable, reporting about 7.9 and 8.5 percent increase, due mainly to the advantages by the cheaper labor and quality of yarn in case of textile garments. The industry output of Auto (3 percent), Pharma (-4 percent), decreased and Insurance (2 percent) decreased as well as Logistics (1) decreased. If Pak-India trade will restore we will win the race in Textile, Agriculture, and auto parts. 
Table 8:Impact of Pak-India Trade on Employment (000 million)

\begin{tabular}{|l|l|l|}
\multicolumn{1}{r}{ Sector } & \multicolumn{1}{c}{ IND } & PAK \\
\hline AGRI & $\mathbf{3 . 8 9}$ & $\mathbf{3 . 8 1 . 1 2}$ \\
\hline PHAR & $\mathbf{1 9 . 1 1}$ & $\mathbf{1 5 . 3 1}$ \\
\hline AUTO & $\mathbf{5 . 8 8}$ & $\mathbf{7 . 5 6}$ \\
\hline TEXT & $\mathbf{8 . 4 6}$ & $\mathbf{1 1 . 1 0}$ \\
\hline OSIISR & $\mathbf{7 . 7 2}$ & -4.21 \\
\hline OTPL & $\mathbf{9 . 6 8}$ & $\mathbf{- 3 . 2 2}$ \\
\hline
\end{tabular}

\section{Source-GTAP-7}

From the Above Table it indicate that if we are going to initiate the trade with India there will be change in the employment in Agriculture, Pharmaceutical, Auto, Textile, Insurance and logistic and transport sector. Negative sign shows that the sectors where Pakistan's not getting benefit, otherwise India has absolutely advantage in the sectors of OSIISR and OTPL sector. The overall results suggests that on MFN status with India there will be positive change in Employment.

\section{Conclusion}

The simulation results presented and analyzed here demonstrate the importance of experimental designs, and the usefulness of the global CGE modeling framework for examining the impacts of the different types of trade policy reforms for Pakistan. The results suggest that Pakistan would experience the highest welfare gain if under the combined policy reform of the SAFTA cum 15 percent uniform external tariffs while the SAFTA on its own gives the second highest welfare gains. SAFTA allows the participating countries to achieve larger economies of scale in production, attain specialization, increase competitiveness and diversify their export basket, thus assisting domestic economic reform. Therefore, harmonizing economic policies among neighboring countries must receive higher priority in the policy making process. Although, simulation results are highly sensitive to the underlying data and assumptions regarding the reference scenarios, the results clearly provide an assessment of the implications of SAFTA. According to the simulation results suggests that there will be positive impact on PAK-INDIA trade on GDP, EXPORT, IMPORT and EMPLOYMENT under various scenarios, of tariff rates should applied like, MFN. $15 \%, 10 \%$ and $8 \%$. Pakistan's has welfare gain of tariff rate 15 $\%$ and $10 \%$ respectively but on $8 \%$ tariff results shows that there will be negative impact on the selected sectors.

\section{References}

1. Centre for Monitoring Indian Economy. (2004). Annual report on Corporate Sector.

2. Government of Pakistan (Various Issues). Census of Manufacturing Industries, Islamabad: Federal Bureau of Statistics.

3. Government of Pakistan (Various Issues). Economic Survey, and Islamabad: Economic Advisor's Wing, Ministry of Finance.

4. Government of Pakistan (Various Issues). Monthly Statistical Bulletin, and Islamabad: Federal Bureau of Statistics

5. Government of Pakistan (Various Issues). Pakistan Custom and Tariffs year Book Islamabad: Central Board of (CB). Revenue

6. Government of India, Annual Report 2003-04, Department of Commerce and trade.

7. Pakistan gulf economist December. (2002). report By M.E JALBANI, Director, EPB.

8. Government of India, (Various Issues). Economic Survey, New Delhi: Economic Division, Ministry of Finance.

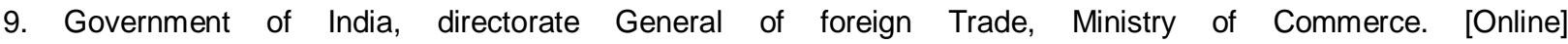
Available:

10. www.dgft.del hi.nic.in.

11. International Financial Statistics, CD-ROM. (2004). International Monetary Fund, Washington DC. 